\title{
Epidemiological and serological aspects of hepatitis A among children and teenagers in the city of Santos: a cross-sectional study
}

\author{
Aspectos epidemiológicos e sorológicos da hepatite A em crianças e adolescentes \\ na cidade de Santos: estudo transversal
}

\author{
Maria Célia Cunha Ciaccia', Regina Célia Moreira", Alexandre Archanjo Ferraro"II, Marcílio Figueiredo Lemos", Isabel Takano Oba", \\ Gilda Portalv
}

Instituto da Criança (ICR), Hospital das Clínicas (HC), Faculdade de Medicina da Universidade de São Paulo (FMUSP), and Virology Service, Instituto Adolfo Lutz, São Paulo, Brazil

\begin{abstract}
'MD, Department of Pediatrics, Instituto da Criança (ICR), Faculdade de Medicina da Universidade de São Paulo (FMUSP), São Paulo, Brazil.

"MD, PhD. Scientific Researcher, Instituto Adolfo Lutz, São Paulo, Brazil.

'"MD, PhD. Professor, Department of Pediatrics, Instituto da Criança (ICR), Hospital das Clínicas $(\mathrm{HC})$, Faculdade de Medicina da Universidade de São Paulo (FMUSP), São Paulo, Brazil.

"MD, PhD. Full Professor, Department of Pediatrics, Instituto da Criança (ICR), Hospital das Clínicas (HC), Faculdade de Medicina da Universidade de São Paulo (FMUSP), São Paulo, Brazil.
\end{abstract}

KEY WORDS:

Prevalence.

Hepatitis A.

Child.

Serology.

Epidemiology.

PALAVRAS-CHAVE:

Prevalência.

Hepatite A.

Criança.

Sorologia.

Epidemiologia.

\begin{abstract}
CONTEXT AND OBJECTIVE:Viral hepatitis A is still a concern at public health level in Brazil and around the world, due both to the number of affected subjects and the possibility of complications in the acute forms. The Brazilian Ministry of Health estimates that at least $70 \%$ of this country's population has already had contact with the hepatitis A virus (HAV). The aim here was to discover the prevalence of serological markers for the hepatitis A virus among children and teenagers at daycare facilities, kindergartens and elementary schools in the city of Santos.

DESIGN AND SETTING: Cross-sectional study in kindergartens and elementary schools within the municipal education network in several regions of the city of Santos.

METHOD: Students' family members were surveyed using a questionnaire and 4,680 finger-prick blood samples were taken and assayed by means of the ELISA technique.

RESULTS: The general prevalence of anti-HAV IgG was $9.72 \%$ and, of these cases, $74.6 \%$ were reactive to antiHAV IgM. There was higher prevalence of anti-HAV IgG among older children, females, children who played in streams, those whose homes were not connected to the sewage system, those whose parents had low education levels, those with low household income and those who did not live along the seashore. The prevalence of anti-HAV IgM peaked in the early years and subsequently fell, and it was lower on the hills and in the Northwestern Zone.

CONCLUSION: The general prevalence of serological markers for hepatitis A was low in Santos.
\end{abstract}

\section{RESUMO}

CONTEXTO E OBJETIVO: A hepatite viral A continua sendo uma preocupação em nível de saúde pública no Brasil e no mundo, tanto pelo número de indivíduos atingidos, como pela possibilidade de complicação das formas agudas. O Ministério da Saúde estima que pelo menos 70\% da população do Brasil já tiveram contato com o vírus da hepatite A. O objetivo foi conhecer a prevalência de marcadores sorológicos do vírus da hepatite A em crianças e adolescentes de creches e escolas de ensino infantil e fundamental na cidade de Santos.

TIPO DE ESTUDO E LOCAL: Estudo transversal em pré-escolas e de ensino fundamental da rede municipal em diversas regiões da cidade de Santos.

MÉTODO: Foi aplicado um questionário aos familiares dos estudantes e coletadas 4.680 amostras de sangue através de punção capilar para realização da sorologia pela técnica ELISA.

RESULTADOS: A prevalência geral do anti-HVA lgG foi de 9,72\% e, desses, 74,6\% foram anti-HVA IgM reagentes. A prevalência de anti-HVA IgG foi maior entre as crianças mais velhas, meninas, aquelas que brincavam em córregos, sem rede de coleta de esgoto em sua moradia, de pais com baixa instrução, de baixa renda familiar e aquelas que não eram moradoras da orla. A prevalência de anti-HVA IgM teve pico nos primeiros anos e posterior queda e, no morro e Zona Noroeste, foi mais baixa.

CONCLUSÃO: A prevalência geral dos marcadores sorológicos para hepatite A foi baixa em Santos.

\section{INTRODUCTION}

Viral hepatitis A is still a concern at public health level in Brazil and around the world, due both to the number of affected subjects and the possibility of complications in the acute forms. The Brazilian Ministry of Health estimates that at least $70 \%$ of this country's population has already had contact with the hepatitis A virus (HAV). ${ }^{1}$

It is known that sanitary and hygiene conditions influence hepatitis A incidence, since the major virus transmission route is fecal-oral. Studies have shown greater hepatitis A prevalence 
with increasing age, ${ }^{2}$ and also with poor socioeconomic and sanitary conditions. ${ }^{2,3}$ In Brazil, Clemens et al. ${ }^{4}$ evaluated the prevalence of anti-HAV among 3653 subjects aged 1 to 40 years, in four Brazilian state capitals: in the Northern region, it was $92.8 \%$; in the Northeastern region, $76.5 \%$; and in the Southern and Southeastern regions, $55.7 \%$.

The severity of the clinical picture is directly related to the patient's age. About $1 \%$ of hepatitis A cases can evolve into the fulminant form. ${ }^{5,6}$ Despite improvements in the socioeconomic conditions of populations, hepatitis A epidemics and outbreaks continue to occur, ${ }^{7}$ even in developed countries, ${ }^{8}$ and they are a major public health problem. Considering that young adults are more susceptible to the infection and that disease severity for this age range is high, healthcare professionals need to be aware of the prevalence of viral hepatitis A in order to identify, evaluate and control epidemics and calculate the impact of vaccination programs. ${ }^{9-12}$ It is worth emphasizing that some studies have showed that vaccination against hepatitis A is capable of preventing disease dissemination during an outbreak, and also of protecting patients' household contacts. ${ }^{13}$

In Brazil, there have been few prevalence studies on population samples representative of hepatitis A. It is therefore difficult to generalize the findings or make comparisons between these studies.

Therefore, we proposed to identify the knowledge of the epidemiological and serological aspects of hepatitis A among children and teenagers enrolled at daycare facilities, kindergartens and elementary schools within the municipal education network of the city of Santos, Brazil. We believe that this is important for enabling actions and policy decisions directed towards the healthcare sector.

\section{OBJECTIVE}

The aim of this study was to assess the prevalence of immunoglobulin $\mathrm{G}(\operatorname{IgG})$ and immunoglobulin $\mathrm{M}(\operatorname{IgM})$ anti-hepatitis A virus (anti-HAV) antibodies, thus revealing any cases of subclinical acute infection by the hepatitis A virus among children and teenagers enrolled in the municipal education network of the city of Santos, according to age range and socioeconomic level.

\section{METHODS}

Santos is the largest city on the coast of the state of São Paulo, with an area of $280,300 \mathrm{~km}^{2}$ and a population of nearly half a million. Its medical care resources are centered around the public healthcare system (Sistema Único de Saúde, SUS) and service agreements. There have not been any really representative evaluations on the prevalence of antibodies against hepatitis A among children and teenagers in Santos.

A cross-sectional study was conducted between June 28 and December 14, 2007, in which 4,680 finger-prick blood samples were collected from children and teenagers enrolled at daycare facilities, kindergartens and elementary schools within the municipal education network in several regions of the city of Santos. At the same time, a survey questionnaire was applied to members of the children and teenagers' families. The following were taken to be exclusion criteria: students who were absent after three requests to take part in the study, those who did not bring the vaccination record card $(n=374)$ and those who had received the vaccine against hepatitis $A(n=57)$ for analysis of the anti-HAV IgG serological markers.

This project was approved by the Ethics Committee of Hospital das Clínicas (HC) and of Faculdade de Medicina da Universidade de São Paulo (FMUSP), by the Ethics Committee of the Health Department of Santos and by the Education Department of Santos. An informed consent statement was presented to the persons responsible for the children and teenagers and, after they had approved it by signing it, the questionnaire was applied and collection of finger-prick blood samples was started.

\section{Operationalization}

The first part of the study consisted of randomizing the students and telephoning their parents or the persons responsible for them, in order to apply a questionnaire seeking information regarding student identification, age, gender, birth date, parents' education level and parents' profession, household income, individual and family history, physical environment and vaccination record card. The second part consisted of carrying out the sample collection and the third part consisted of laboratorial testing.

\section{Sample calculation}

This study was part of a population survey about the prevalence of hepatitis A, B and C. To determine the sample size, an expected frequency of $1 \%$ (the expected frequency of hepatitis $B$ would be less than this), acceptable error of $0.5 \%$ and confidence level of 95\% were calculated using the Epi Info software, version 6. The total population was 29,589 students enrolled within the municipal education network of Santos: 2,050 at daycare facilities, 6,079 in kindergartens, 16,026 in elementary school from $1^{\text {st }}$ to $4^{\text {th }}$ grade and 5,434 teenagers from $5^{\text {th }}$ to $8^{\text {th }}$ grade. From this population, the total sample achieved was 4,680 students, i.e. $880,1,220,1,390$ and 1,190 , respectively for each education stratum. The sample was then divided into equally sized groups in each of five regions of the City of Santos. The regions for this study were chosen based on the socioeconomic differences that exist among them.

In each of these regions, two daycare facilities were randomized (except for the hill region, where three daycare facilities were randomized, since the sufficient number was not reached with only two), as well as two kindergarten education units, two elementary schools from $1^{\text {st }}$ to $4^{\text {th }}$ grade and two from $5^{\text {th }}$ to $8^{\text {th }}$ grade. In each school unit, the classes and the number of students in each of them were randomized, always in equal sizes, until the total number for the sample was reached. 
Table 1. General prevalence of the anti-HAV IgG and anti-HAV IgM serological markers when anti-HAV IgG was reactive

\begin{tabular}{lcc} 
& \multicolumn{2}{c}{$\mathbf{n ( \% )}$} \\
\cline { 2 - 3 } Non-reactive & Anti-HAV IgG & Anti-HAV lgM \\
Reactive & $3,836(90.3)$ & $105(25.4)$ \\
Total & $413(9.7)$ & $308(74.6)$ \\
\hline
\end{tabular}

Table 2. Prevalence of reactive serological findings for anti-HAV IgG and anti-HAV IgM (subsample of individuals who were lgG-positive), according to the characteristics of the population

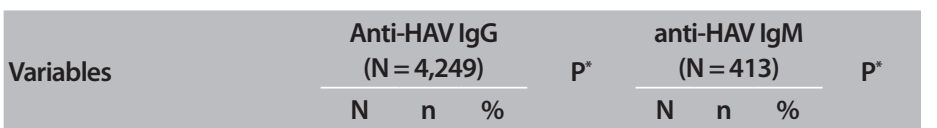

\section{Education groups}

\begin{tabular}{|c|c|c|c|c|c|c|c|c|}
\hline Daycare facility & 835 & 21 & 2.5 & \multirow{4}{*}{$<0.001^{+}$} & 21 & 16 & 76.2 & \multirow{4}{*}{$<0.001^{\dagger}$} \\
\hline Kindergarten & 1,188 & 65 & 5.5 & & 65 & 60 & 92.3 & \\
\hline Elementary $1^{\text {st }}-4^{\text {th }}$ & 1,263 & 192 & 15.2 & & 192 & 167 & 87.0 & \\
\hline Elementary $5^{\text {th }}-8^{\text {th }}$ & 963 & 135 & 14.0 & & 135 & 63 & 46.7 & \\
\hline \multicolumn{9}{|l|}{ Gender } \\
\hline Male & 2,119 & 186 & 8.8 & \multirow{2}{*}{0.039} & 186 & 137 & 73.7 & \multirow{2}{*}{0.855} \\
\hline Female & 2,130 & 227 & 10.7 & & 227 & 169 & 74.5 & \\
\hline \multicolumn{9}{|l|}{ Playing in streams } \\
\hline No & 3,990 & 358 & 9.0 & \multirow{2}{*}{$<0.001$} & 358 & 265 & 74.0 & \multirow{2}{*}{0.934} \\
\hline Yes & 258 & 55 & 21.3 & & 55 & 41 & 74.6 & \\
\hline \multicolumn{9}{|c|}{ Home connected to sewage system } \\
\hline Yes & 3,812 & 341 & 9.0 & \multirow{2}{*}{$<0.001$} & 341 & 252 & 73.9 & \multirow{2}{*}{0.847} \\
\hline No & 434 & 72 & 16.6 & & 72 & 54 & 75 & \\
\hline
\end{tabular}

Father's education level

$\begin{array}{lcccccccc}\text { Illiterate } & 106 & 24 & 22.6 & & 24 & 15 & 62.5 & \\ \text { Incomplete elementary } & 1,514 & 233 & 15.4 & & 233 & 168 & 72.1 & \\ \text { Completed elementary } & 673 & 57 & 8.5 & & 57 & 45 & 79.0 & \\ \text { Incomplete high school } & 390 & 16 & 4.1 & <0.001^{\dagger} & 16 & 14 & 87.5 & 0.135^{\dagger} \\ \text { Completed high school } & 1,050 & 38 & 3.6 & & 38 & 28 & 73.7 & \\ \text { University-level education } & 221 & 7 & 3.8 & 7 & 5 & 71.4 & \\ \text { Mother's education level } & & & & & & & \\ \text { Illiterate } & 97 & 24 & 24.7 & & 24 & 15 & 62.5 & \\ \text { Incomplete elementary } & 1,479 & 238 & 16.1 & & 238 & 179 & 75.2 & \\ \text { Completed elementary } & 626 & 52 & 8.3 & & 52 & 39 & 75.0 & \\ \text { Incomplete high school } & 469 & 27 & 5.8 & 0.001^{+} & 27 & 24 & 88.9 & 0.920^{\dagger} \\ \text { Completed high school } & 1,346 & 55 & 4.1 & & 55 & 37 & 67.3 & \\ \text { University-level education } & 197 & 8 & 4.1 & & 4 & 50.0 & \end{array}$

\section{Family income}

1-2 minimum wages

3-4 minimum wages

$5+$ minimum wages

\section{Areas}

Seashore

Center

Intermediate

Hills

Northwestern Zone

$\begin{array}{cccccccc}2,320 & 301 & 13.0 & & 301 & 225 & 74.8 & \\ 1431 & 95 & 6.6 & <0.001^{+} & 95 & 70 & 73.7 & 0.558^{+} \\ 495 & 17 & 3.4 & & 17 & 11 & 64.7 & \\ & & & & & & & \\ 839 & 49 & 5.8 & & 49 & 36 & 73.5 & \\ 876 & 95 & 10.8 & & 95 & 83 & 87.4 & \\ 854 & 90 & 10.5 & 0.001 & 90 & 74 & 82.2 & <0.001 \\ 769 & 80 & 10.4 & & 80 & 55 & 68.8 & \\ 911 & 99 & 10.9 & & 99 & 58 & 58.6 & \end{array}$

$\mathrm{N}=$ total sample; $\mathrm{n}$ = sample with positive serological test; $\%=$ prevalence of positivity in the serological testing; the incongruence of some results from addition is due to 'missing data'; *Chi-square; 'Chi-square for trend.

\section{Sample collection}

The blood collection consisted of finger puncture using an appropriate disposable lancet, on a filter paper containing two circles of 2.5 centimeters in diameter. After collection, the filter paper with the student's identification remained for two hours in a container for drying and was then stored at $-20^{\circ} \mathrm{C}$ in closed small transparent plastic bags. The serological tests performed were IgG anti-HAV and IgM anti-HAV (the latter was performed when IgG was positive), by means of the enzyme immunoassay. The tests were carried out in the Hepatitis Laboratory of Institute Adolfo Lutz, in São Paulo.

\section{Data processing and analysis}

The analysis was done with the aid of the Stata software, version 9.0. To compare means, we used the Mantel-Haenszel chi-square and the chi-square trend for ordinal categories. For risk analysis, we calculated the prevalence ratio according to category, and its 95\% confidence interval, using Poisson regression. To ascertain the effect of independent variables, multivariate Poisson regression was used, with the calculation of the linear trend or heterogeneity in cases in which there was more than one risk category. The contributors in this analysis were 3928 individuals whose data were complete. The value for rejecting the null hypothesis was set at $\mathrm{P}<0.05$.

\section{RESULTS}

The ages of the study population ranged from seven months to 18 years and one month, and the mean age was eight years and four months. The general prevalence of reactive anti-HAV IgG serological markers was $9.72 \%$ and, among these individuals, $74.7 \%$ were also found to be reactive to anti-HAV IgM, as shown in Table 1.

In the cases that were reactive to the anti-HAV IgG and IgM serological markers, the prevalence of evident symptoms or knowledge of ever having had hepatitis, on the part of the student or his/her family, was low. Most of them said that they had never had any symptoms and were unaware of ever having had hepatitis (95.6\%). Among the symptoms presented, jaundice was the most frequent (3.9\%).

Table 2 shows the prevalence of anti-HAV IgG and IgM among the population. All the variables were statistically associated with presence of anti-HAV IgG, with higher prevalence among older children, females, children who were in the habit of playing in streams, those whose homes were not connected to the sewage system, those whose parents had low education levels, those with low family income and those who did not live along the seashore (no differences between the other areas).

The prevalence of anti-HAV IgM, as shown in Table 2, did not differ between the categories, except for the age (peak in the early years and subsequent fall) and the area of the city (lower on the hills and in the Northwestern Zone). 
Table 3 shows the risk associated with each category of the variable studied for IgG antibody positivity. The greatest risks were associated with parental education (prevalence reason, $\mathrm{PR}=7.15$ with $95 \%$ confidence interval, CI, of 3.08-16.59 for the father to be illiterate; and $\mathrm{PR}=6.09$ with $95 \% \mathrm{CI}$ of $2.74-13.56$ for the mother to be illiterate), and the lowest risk was associated with family income ( $\mathrm{PR}=0.26$ with $95 \% \mathrm{CI}$ of $0.16-0.43$ for the family to be wealthy).

Multivariate analysis on anti-HAV IgG positivity showed that the variables were all independent of each other, except for gender and the area of the city, and were not statistically significant. The greatest risk was among the teenagers: 6.11 times higher than among the children in daycare.

\section{DISCUSSION}

The sampling of this study was probabilistic, thus assuring its representativeness, and the proportions were maintained when age ranges according to the census data were used.

The use of capillary blood collected on a filter paper for serological testing facilitates the collection, transportation and storage of the samples, and the results reported in the literature already show that such testing is valid for hepatitis A investigations. ${ }^{14}$ Thus, blood collection by means of a lancet on filter paper for determining antibody levels provides an excellent opportunity to investigate diseases in representative populations.

The presence of anti-HAV IgG indicates previous exposure to the virus or vaccination. Determination of its prevalence enables evaluation of the immunological condition of such populations of children and teenagers without vaccination against HAV, thus indicating natural infection. The general prevalence of serological markers for hepatitis A in our study (9.7\%) was lower than in other regions of Brazil, with reports ranging from $32.3 \%$ in the Central-Western region, ${ }^{15}$ in 2008 , to $60 \%$ among children under the age of 10 years in Lábrea, in the Brazilian Western Amazon region, ${ }^{16}$ in 2009. Regarding worldwide epidemiology, variations have been found, depending on the location. ${ }^{17,18}$ It was found to be rare in Japan, ${ }^{18}$ among subjects under the age of 44 years, and reached up to $80 \%$ in Turkey, ${ }^{19}$ among children under the age of nine years.

We found that anti-HAV IgG was more prevalent among females, which had not been reported in the majority of the data in the literature. In the semi-arid region of the state of Bahia, ${ }^{20}$ and in the Brazilian Western Amazon region ${ }^{20}$ among children between 6 months and 14 years of age, the prevalence of these markers was found to be similar between the genders.

The strong relationship between positivity of anti-HAV IgG and socioeconomic conditions found in the present study is concordant with the data in the literature. Pinho et al. ${ }^{3}$ showed that the prevalence of anti-HAV IgG in Campinas was 95\% in the group of low socioeconomic level and $19.6 \%$ in the group of high socioeconomic level. Ferreira et al. ${ }^{2}$ evaluated the relationship
Table 3. Uni and multivariate analysis on the risk of positive findings of antiHAV IgG relating to presence of characteristics of the population $(n=3,928)$

\begin{tabular}{|c|c|c|c|c|c|c|}
\hline \multirow[t]{2}{*}{ Variable } & \multicolumn{3}{|c|}{ Univariate analysis } & \multicolumn{3}{|c|}{$\begin{array}{c}\text { Multivariate analysis } \\
\text { (variables reciprocally } \\
\text { adjusted) }\end{array}$} \\
\hline & PR & $95 \% \mathrm{Cl}$ & $\mathbf{P}$ & PR & $95 \% \mathrm{Cl}$ & $P$ \\
\hline \multicolumn{7}{|l|}{ Groups educations } \\
\hline Daycare facility & 1.00 & & \multirow{4}{*}{$<0.001^{*}$} & 1.00 & & \multirow{4}{*}{$<0.001^{*}$} \\
\hline Kindergarten & 2.18 & $1.33-3.56$ & & 2.21 & $1.28-3.80$ & \\
\hline Elementary $1^{\text {st }}-4^{\text {th }}$ & 6.04 & $3.85-9.48$ & & 5.81 & $3.52-9.61$ & \\
\hline Elementary $5^{\text {th }}-8^{\text {th }}$ & 5.57 & $3.52-8.83$ & & 6.11 & $3.67-10.19$ & \\
\hline \multicolumn{7}{|l|}{ Gender } \\
\hline Male & 1.00 & & \multirow{2}{*}{0.050} & 1.00 & & \multirow{2}{*}{0.373} \\
\hline Female & 1.21 & $1.00-1.47$ & & 1.10 & $0.89-1.35$ & \\
\hline \multicolumn{7}{|l|}{ Playing in streams } \\
\hline No & 1.00 & & \multirow{2}{*}{$<0.001$} & 1.00 & & \multirow{2}{*}{0.006} \\
\hline Yes & 2.38 & $1.79-3.16$ & & 1.54 & $1.13-2.10$ & \\
\hline \multicolumn{7}{|c|}{ Home connected to sewage system } \\
\hline Yes & 1.00 & & \multirow{2}{*}{$<0.001$} & 1.00 & & \multirow[b]{2}{*}{0.041} \\
\hline No & 1.85 & $1.44-2.39$ & & 1.36 & $1.01-1.84$ & \\
\hline \multicolumn{7}{|l|}{ Father's education level } \\
\hline Illiterate & 7.15 & 3.08-16.59 & \multirow{6}{*}{$<0.001^{*}$} & 3.02 & $1.21-7.48$ & \multirow{6}{*}{$<0.001^{*}$} \\
\hline Incomplete elementary & 4.86 & $2.29-10.30$ & & 2.35 & $1.05-5.26$ & \\
\hline Completed elementary & 2.67 & $1.22-5.86$ & & 1.79 & $0.78-4.11$ & \\
\hline Incomplete high school & 1.30 & $0.53-3.15$ & & 1.05 & $0.42-2.66$ & \\
\hline Completed high school & 1.14 & $0.51-2.56$ & & 1.11 & $0.48-2.53$ & \\
\hline $\begin{array}{l}\text { University-level } \\
\text { education }\end{array}$ & 1.00 & & & 1.00 & & \\
\hline \multicolumn{7}{|l|}{ Mother's education level } \\
\hline Illiterate & 6.09 & $2.74-13.56$ & \multirow{6}{*}{$<0.001^{*}$} & 1.80 & $0.74-4.38$ & \multirow{6}{*}{$<0.001^{*}$} \\
\hline Incomplete elementary & 3.96 & $1.96-8.02$ & & 1.32 & $0.61-2.85$ & \\
\hline Completed elementary & 2.05 & $0.97-4.31$ & & 0.87 & $0.39-1.94$ & \\
\hline Incomplete high school & 1.42 & $0.64-3.12$ & & 0.80 & $0.34-1.85$ & \\
\hline Completed high school & 1.01 & $0.48-2.11$ & & 0.67 & $0.31-1.45$ & \\
\hline $\begin{array}{l}\text { University-level } \\
\text { education }\end{array}$ & 1.00 & & & 1.00 & & \\
\hline \multicolumn{7}{|l|}{ Family income } \\
\hline $1-2$ minimum wages & 1.00 & & \multirow{3}{*}{$<0.001^{*}$} & 1.00 & & \multirow{3}{*}{$0.001^{*}$} \\
\hline 3-4 minimum wages & 0.51 & $0.41-0.64$ & & 0.69 & $0.54-0.90$ & \\
\hline $5+$ minimum wages & 0.26 & $0.16-0.43$ & & 0.52 & $0.31-0.88$ & \\
\hline \multicolumn{7}{|l|}{ Areas } \\
\hline Seashore & 1.00 & & & 1.00 & & \\
\hline Center & 1.86 & $1.31-2.62$ & \multirow{4}{*}{$0.003^{\dagger}$} & 1.35 & $0.94-1.94$ & \\
\hline Intermediate & 1.80 & $1.27-2.56$ & & 1.33 & $0.92-1.93$ & $0.513^{+}$ \\
\hline Hills & 1.78 & $1.25-2.54$ & & 1.19 & $0.82-1.73$ & \\
\hline Northwestern Zone & 1.86 & $1.32-2.62$ & & 1.27 & $0.88-1.84$ & \\
\hline
\end{tabular}

$\mathrm{PR}=$ prevalence ratio; $95 \% \mathrm{Cl}=95 \%$ confidence interval; ${ }^{*}$ testing of linear trends; testing of heterogeneity.

between the prevalence of hepatitis A and socioeconomic level in Porto Alegre, and found that the prevalence was $51 \%$ in the low-level group, and $11 \%$ in the high-level group. In Vila Velha, Espírito Santo, ${ }^{21}$ there was a correlation between positive serological tests for hepatitis A and lower access to filtered water, lower access to the sewage system, habits of swimming in rivers or the sea and a greater number of people living in the same room. In the Brazilian Western Amazon region, ${ }^{16}$ it was also associated with a greater number of people in the family. In Greece, ${ }^{22}$ a strong relationship was shown between positive serological tests for hepatitis A and a low level of education among the parents, a greater number of people per room and lower access to water, among children with an average age of nine years. 
In our series, we observed that a large number of teenagers were at high risk of infection, because even with the gradual increase in prevalence of anti-HAV IgG antibodies, it remained low. Clemens et al. ${ }^{4}$ showed that the prevalence of anti-HAV IgG antibodies increased with age, in four Brazilian regions.

We observed that there had been an outbreak of hepatitis A virus, by analyzing the positivity of anti-HAV IgM. We found in this study that there was no influence from the presence or absence of a connection to the sewage system among these children's homes, or from the habit of playing in streams near their homes.

Most of the children who were reactive to anti-HAV IgM did not show any symptoms, and these data are in agreement with the literature. No liver enzyme tests were performed in most of these children with the presence of anti-HAV IgM, because they were asymptomatic. Vitral et al. ${ }^{23}$ demonstrated in a review of the literature covering 1980 to 2002, in Brazil, that infection by the hepatitis A virus is very often asymptomatic or develops without jaundice in children, and that the symptoms increase with age.

The high proportion of asymptomatic cases in lower age ranges probably makes it difficult to estimate the magnitude of the events and to decide on timely intervention measures that would prevent diffusion of epidemics. In this manner, the infection reaches older age groups. Continuing presence of susceptibility to hepatitis A virus among adults indicates that although the socio-environmental conditions may have improved, cases of acute disease at adult ages can still occur, with the possibility of greater severity. At the same time, since there are younger children susceptible to the virus, studies on vaccination strategies can be designed, given that this is a common disease that is preventable through immunization.

Although our data confirm that a change in the epidemiological profile of hepatitis A has taken place, the current preventive measures regarding sanitation, education level and housing still remain deficient in Santos, the coastal city with the largest port in Brazil.

Based on these epidemiological data, we call on government spheres to make a response directed towards dealing with this major public health problem. Despite socioeconomic improvements, a number of environmental factors have remained unchanged over the years, such as poor conditions of hygiene and family education; unsuitable sanitary conditions; inadequate sewage system provision by the local administration; and the authorities' inability to resolve the lack of sewage network in such a way that transmission of infections can be prevented: not only hepatitis A, but also other enteric infections.

\section{CONCLUSIONS}

It is concluded in this study that the general prevalence of serological markers for hepatitis A was low, compared with the literature.

\section{REFERENCES}

1. Brasil. Ministério da Saúde. Secretaria de Vigilância em Saúde. Departamento de Vigilância Epidemiológica. Hepatites virais: o Brasil está atento. Brasília: Ministério da Saúde; 2005. Available from: http:// portal.saude.gov.br/portal/arquivos/pdf/hepatites_virais_brasil_ atento.pdf. Accessed in 2011 (Nov 29).

2. Ferreira CT, Silva GL, Barros FC, Ferreira-Lima J. Soroepidemiologia da hepatite A em dois grupos populacionais economicamente distintos de Porto Alegre [Serum epidemiology of hepatitis A in two economically distinct population groups of Porto Alegre]. GED Gastroenterol Endosc Dig. 1996;15(3):85-90.

3. Pinho JRR, Sumita LM, Moreira RC, et al. Duality of patterns in hepatitis a epidemiology: a study involving two socioeconomically distinct populations in Campinas, São Paulo State, Brazil. Rev Inst Med Trop São Paulo. 1998;40(2):105-6.

4. Clemens SA, Da Fonseca JC, Azevedo T, et al. Soroprevalência para hepatite A e hepatite B em quatro centros no Brasil [Hepatitis A and hepatiti B seroprevalence in four centers in Brazil]. Rev Soc Bras Med Trop. 2000;33(1):1-10.

5. Ferreira CT, Silveira TR. Hepatites virais: aspectos da epidemiologia e da prevenção [Viral Hepatitis: epidemiological and preventive aspects]. Rev Bras Epidemiol. 2004;7(4):473-87.

6. Centro de Vigilância Epidemiológica "Prof. Alexandre Vranjac". Secretaria de Estado da Saúde São Paulo. Guia de orientações técnicas. Hepatites B e C. São Paulo: Secretaria de Estado da Saúde São Paulo; Centro de Vigilância epidemiológica "Prof. Alexandre Vranjac"; 2002. Available from: ftp://ftp.cve.saude.sp.gov.br/doc_tec/ outros/hepa_guia03.pdf. Accessed in 2011 (Nov 29).

7. Carrilho FJ, Mendes Clemente C, Silva LC. Epidemiology of hepatitis A and E virus infection in Brazil. Gastroenterol Hepatol. 2005;28(3):118-25.

8. Tosti ME, Spada E, Romanò L, et al. Acute hepatitis A in Italy: incidence, risk factors and preventive measures. J Viral Hepat. 2008;15 Suppl 2: 26-32.

9. Franca R, Silva L, Melo MC, et al. Pediatric knowledge about acute viral hepatitis. Braz J Infect Dis. 2004;8(3):227-35.

10. American Academy of Pediatrics Committee on Infectious Diseases. Hepatitis A vaccine recommendations. Pediatrics. 2007;120(1):189-99.

11. Dominguez A, Oviedo M, Carmona G, et al. Impact and effectiveness of a mass hepatitis A vaccination programme of preadolescents seven years after introduction. Vaccine. 2008;26(14):1737-41.

12. Ferreira $C T$, Silveira TR. Prevenção das hepatites virais através de imunização [Viral hepatitis prevention by immunization]. J Pediatr (Rio J). 2006;82(3 supl):s55-s66.

13. Stein-Zamir C, Volovik I, Rishpon S. Control of Hepatitis A outbreaks in an endemic community: the role of sustained immunization coverage. Public Health. 2007;121(3):199-201.

14. de Almeida LM, Azevedo RS, Guimarães AA, et al. Detection of antibodies against hepatitis A virus in eluates of blood spotted on filter-paper: a pilot study in Rio de Janeiro, Brazil. Trans R Soc Trop Med Hyg. 1999;93(4):401-4. 
15. de Alencar Ximenes RA, Martelli CM, Merchán-Hamann E, et al. Multilevel analysis of hepatitis A infection in children and adolescents: a household survey in the Northeast and Central-west regions of Brazil. Int J Epidemiol. 2008;37(4):852-61.

16. Braga WS, Borges FG, Barros Júnior GM, et al. Prevalence of hepatitis A virus infection: the paradoxical example of isolated communities in the western Brazilian Amazon region. Rev Soc Bras Med Trop. 2009;42(3):277-81.

17. Al-AzizAM,AwadMA.Seroprevalence ofhepatitis Avirus antibodiesamong a sample of Egyptian children. East Mediterr Health J. 2008;14(5):1028-35.

18. Kiyohara T, Sato T, Totsuka A, et al. Shifting seroepidemiology of hepatitis A in Japan, 1973-2003. Microbiol Immunol. 2007;51(2):185-91.

19. Ceyhan M, Yildirim I, Kurt N, et al. Differences in hepatitis A seroprevalence among geographical regions in Turkey: a need for regional vaccination recommendations. JViral Hepat. 2008;15 Suppl 2:69-72.

20. Assis SB, Souto FJD, Fontes CJF, Gaspar AMC. Prevalência da infecção pelos vírus das hepatites $\mathrm{A}$ e $\mathrm{E}$ em escolares de município da Amazônia Matogrossense [Prevalence of hepatitis A and E virus infection in school children of an Amazonian municipality in Mato Grosso State]. Rev Soc Bras Med Trop. 2002;35(2):155-8.

21. Zago-Gomes MP, Stantolin GC, Perazzio S, et al. Prevalence of antihepatitis A antibodies in children of different socioeconomic conditions in Vila Velha, ES. Rev Soc Bras Med Trop. 2005;38(4):285-9.

22. Michos A, Terzidis A, Kalampoki V, et al. Seroprevalence and risk factors for hepatitis $A, B$, and $C$ among Roma and non-Roma children in a deprived area of Athens, Greece. J Med Virol. 2008;80(5):791-7.

23. Vitral $C L$, Gaspar AM, Souto FJ. Epidemiological pattern and mortality rates for hepatitis A in Brazil, 1980-2002--a review. Mem Inst Oswaldo Cruz. 2006;101(2):119-27.

Acknowledgements: We are grateful for assistance relating to the references provided by Mariza Umetsu, Instituto da Criança (ICR), Hospital das Clínicas (HC), Faculdade de Medicina da Universidade de São Paulo (FMUSP)

Sources of funding: Fundação de Amparo à Pesquisa do Estado de São Paulo (Fapesp), Grant no. 06/599728

Conflict of interest: None

Date of first submission: July 2, 2011

Last received: October 14, 2011

Accepted: December 15, 2011

\section{Address for correspondence:}

Maria Célia Cunha Ciaccia

Rua Ceará, 31/81

Pompéia - Santos (SP) - Brasil

CEP 11065-430

Tel. (+55 13) 3239-6338

Cel. (+55 13) 9700-0409

E-mail: ciaccia@uol.com.br 